\title{
Increased short-term mortality among normothermic patients presenting to a medical emergency department with infection - a cohort study
}

\author{
Daniel P Henriksen ${ }^{1 *}$, Helene CK Jensen ${ }^{1}$, Christian B Laursen², Annmarie T Lassen ${ }^{1}$ \\ From 6th Danish Emergency Medicine Conference \\ Odense, Denmark. 20-21 November 2014
}

\section{Background}

Infections are frequent causes of medical admissions to the emergency department (ED). However, not all infected patients present with fever $\left(>38^{\circ} \mathrm{C}\right)$. The aim of the study was to assess differences in short-term mortality among patients hospitalized with community-acquired infection presenting with and without fever.

\section{Methods}

All adult patients ( $\geq 15$ years) with a first-time admission at a medical ED between September 2010-August 2011 with community-acquired infection were included. Cases were identified by manual chart review using predefined criteria of infection. Data on vital signs, laboratory values and antibiotic treatment were obtained electronically. We excluded unidentified patients and patients residing outside the hospitals catchment area. To assess if the absence of fever (normothermia: $36.0-38.0^{\circ} \mathrm{C}$ ) is an independent prognostic factor, we computed multiple Cox regression analyses, adjusted for different potential confounders.

\section{Results}

1,901 patients with infection, treated with antibiotics within 24 hours after arrival, were included. Median age was 74 years (5-95\% range: $29-92$ years); $896(47.1 \%)$ were males, and $811(42.7 \%)$ presented with a Charlson Comorbidity Index $>2 ; 49.7 \%$ were normothermic at arrival and $50.3 \%$ presented with fever. Thirty-day mortality was 9.3\% (95\% CI: 7.5-11.3\%) among patients with fever and 18.1\% (95\% CI: 15.7-20.7\%) in normothermic patients. The unadjusted hazard ratio (HR) of death within 30 days after admission in normothermic

${ }^{1}$ Medical Emergency Department, OUH Odense University Hospital, Odense, Denmark

Full list of author information is available at the end of the article infectious patients was 2.2 (95\% CI: 1.7-2.8) compared to infectious patients with fever, adjusted HR 2.0 (95\% CI: 1.6-2.6).

\section{Conclusion}

Normothermic patients admitted with an infection were twice as likely to die within 30 days after admission compared to infectious patients admitted with fever.

\section{Authors' details}

'Medical Emergency Department, OUH Odense University Hospital, Odense, Denmark. ${ }^{2}$ Department of Respiratory Medicine, OUH Odense University Hospital, Odense, Denmark.

Published: 16 July 2015

doi:10.1186/1757-7241-23-S1-A26

Cite this article as: Henriksen et al:: Increased short-term mortality among normothermic patients presenting to a medical emergency department with infection - a cohort study. Scandinavian Journal of Trauma, Resuscitation and Emergency Medicine 2015 23(Suppl 1):A26.

Submit your next manuscript to BioMed Central and take full advantage of:

- Convenient online submission

- Thorough peer review

- No space constraints or color figure charges

- Immediate publication on acceptance

- Inclusion in PubMed, CAS, Scopus and Google Scholar

- Research which is freely available for redistribution 